\title{
CONVENTIONAL AND UNCONVENTIONAL MONETARY POLICY. THE CASE OF ROMANIA
}

\author{
Pleșcău Ioana \\ Alexandru Ioan Cuza University of Iași \\ ioana.plescau@yahoo.com
}

\begin{abstract}
The aim of our paper is to analyze the conventional and unconventional monetary policy in Romania, in the context of the recent financial crisis. We study the relationship between interest rates and credit risk, but also the non-standard monetary measures that were adopted by the National Bank of Romania and their impact on the banking system. Our results point to a decrease of interest rates in the years after the crisis, which is in line with the majority of central banks that have reduced monetary rates in order to sustain the economy and the credit activity.
\end{abstract}

\section{Keywords}

conventional monetary policy; unconventional monetary policy; financial crisis; bank risk; interest rate

\section{JEL Classification}

E40; E52; E58; G01

\section{Introduction}

After the outbreak of the recent financial crisis, the major central banks have tried to adopt the best strategies in order to sustain the banking system and avoid a collapse of it. The major central banks have made full use of their standard instrument of monetary policy, the interest rate, and have employed very low levels of it. The purpose was to set such a level for the interest that could encourage de consumption and increase the aggregate output. However, the economy has reached a point where, in spite of the very low level of the interest rate, the economic stability did not improve and the major central banks tried to find new instruments that could improve the health of the economic system.

The financial crisis that started in late 2007 has questioned some theories from different areas and it has proven the need to reconsider the economic and monetary theories regarding the financial and economic stability, but also the way in which the financial sector interacts with the monetary one.

One of the most debated topics in the recent monetary literature regards the design of the monetary policy after the outbreak of the financial crisis and the effects that the new instruments of monetary policy have on the macro-economy, in general, and on the banking system, in particular. This is the motivation that drives the existence of this study. We aim at making a short review of the traditional monetary policy instrument - the interest rate- in order to capture its evolution after the recent financial crisis and to analyze the effects of the interest rate adopted by the National Bank of Romania in the period 2005-2012. 


\section{Literature review}

In recent years the literature that focuses on monetary policy and its effects makes a distinction, somehow not so clear, between the conventional and unconventional monetary policy. This distinction became more and more used after the outbreak of the financial crisis when central banks reduced the interest rates (conventional instruments) until they hit the zero-lower bound and start to design some new instruments - the so-called unconventional measures of monetary policy. But what are these measures? Why are they so unconventional?

Borio and Disyatat (2009) discuss the unconventional monetary measures in the context of implementing the monetary policy and make a classification of these measures and their transmission mechanisms. The authors argues that, in essence, the measures adopted after the 2008 financial crisis are not so unconventional, better said the purpose of each of them is untraditional. Comparing the conventional and unconventional monetary measures, Borio and Disyatat (2009) name the first category as interest-rate policy, while the second category is called balance-sheet policy. This last category comprises four types of interventions: exchange rate policy, loan policy, debt-management policy and the management of central bank reserves. Also, Borio and Disyatat (2009) classifies the unconventional measures in two categories: measures of credit easing and measures of quantitative easing.

Regarding the theoretical foundations of the unconventional monetary policy, there are studies that highlight the role they had in the period before the financial crisis. Bernanke and Reinhart (2004) discuss the most important unconventional monetary measures, but also the way a central bank can accommodate both the conventional and unconventional instruments. Moreover, Bernanke and Reinhart (2004) analyze three unconventional policies that a central bank could use when the monetary interest rate reaches the zero-lower bound. This is the situation that come up after the outbreak of the 2008 financial crisis. These three unconventional measures are: the forward guidance regarding the path of the interest rate, the changing composition of the central bank balance sheet and the changing volume of it. We can observe that the measures discussed by Bernanke and Reinhart in 2004 are exactly the anti-crisis measures that were adopted starting in early 2008. Regarding the way a central bank should accommodate the conventional and unconventional measures, Bernanke and Reinhart (2004) argues that the monetary authority has to be very careful not to send to the public the wrong message that, once the interest rate hit the zero-lower bound, the monetary policy becomes inefficient. This idea is discussed in Friedman (2015) also, when he supports the use of some new instruments of monetary policy, together with the interest rates at zero-lower bound, in order to sustain the economy.

The most used unconventional monetary measure is the quantitative easing, that was implemented on a large-scale in Japan after the crisis in yearly 1990s and in United Stated of America and Eurozone, after the 2008 financial crisis. Basically, the quantitative easing means the purchases of long-term financial assets in exchange of the injections of liquidities that the central banks makes in order to encourage the economic growth. The quantitative easing is a method that was used in the monetary practice even before the 2008 financial crisis, but the implementation of it after 2008 focused not only on government bonds, but also on corporate bonds and other types of privately-held assets. Borio and Disyatat (2009) argues that the credit easing that was largely used by the European Central Bank and the forward guidance of the path of interest rates are monetary measures that are strictly unconventional and that were designed to save the banking system from a collapse.

The effects of the large-scale asset purchases, as an unconventional monetary policy instrument, need to be studied in terms of the quantity of assets, but also in terms of the structure of central bank balance sheet. 
Friedman (2015) argues that the effects of the changes in the structure of central bank balance sheet, in terms of assets need to be analyzed by taking into account the quantity of assets, but also the structure of the assets traded on the financial markets. As an example, the Federal Reserves Bank from United States has purchased not only long term financial assets, but also mortgage-backed securities, although the aims of the two are different. In the first case, the central bank wants to influence the longterm interest rate, while in the second case, the central bank wants to influence the interest rate from the mortgage market.

Regarding the empirical evidence on the effects of unconventional monetary policy, there are some studies that demonstrates the positive effects of these measures in United States of America. For example, Baumeister and Benati (2010) analyze the impact of unconventional monetary policy in USA, England and Japan and their results show that the quantitative easing help to stabilize the economy and to avoid the deflation risks. Peersman (2011) studies the unconventional measures adopted by the European Central Bank and they argue that the credit easing lead to higher levels of bank risk in the Eurozone. All in all, when talking about the effects of unconventional monetary measures, there is not a consensus in the literature on whether they had beneficial effects.

\section{Methodology and data}

The main paper on which we construct our empirical analysis is Andrieș, Cocriș and Pleșcău (2015) who investigates the risk-taking channel of monetary policy. Hence, our paper is a contribution to the existing empirical literature that study the impact of monetary policy in the banking system, in general, and on the bank risks, in particular.

We collect data on the commercial banks in Romania and make a panel dataset of 68 observations including 11 banks analyzed on a period of 8 years.

We use the Panel Least Squares estimation method with cross-section fixed effects and the model that we estimate takes the following form:

$$
B C R_{i, t}=\alpha+\beta_{1} * I R_{i, t}+\beta_{2} * I R_{i, t} * C R I S I S+\beta_{3} * b c_{i, t}++\varepsilon_{i j, t},
$$

where BCR is the bank credit risk, IR is the monetary policy rate, $b c_{i, t}$ is a vector of bank-level control variables and CRISIS is a dummy variable that takes the value of 0 in the period 2005 to 2007 and the value of 1 in the period from 2008 to 2012. The role of this dummy variable is to investigate whether the 2008 financial crisis has some impact on the relationship between Romania interest rate and the credit risk of commercial banks from the Romania banking system.

We use the Bankscope database to collect data for the commercial banks in Romania and the National Bank of Romania website to collect data on the official monetary policy rate. Our dependent variable is the bank credit risk that captures the nonperforming loans that could jeopardize the bank activity. The independent variable is the monetary policy interest rate established by the National Bank Romania. We include in our model three control variables in order to control for the unobserved heterogeneity of bank-level characteristics. Our control variables are capitalization, profitability and bank size (computed as the natural logarithm of total assets).

As we can notice in Figure 1, the credit risk exhibits a continuous growth in the period after the outbreak of the financial crisis. We believe that this may be motivated by the impossibility of some borrowers to repay the loans they took from the commercial banks. 


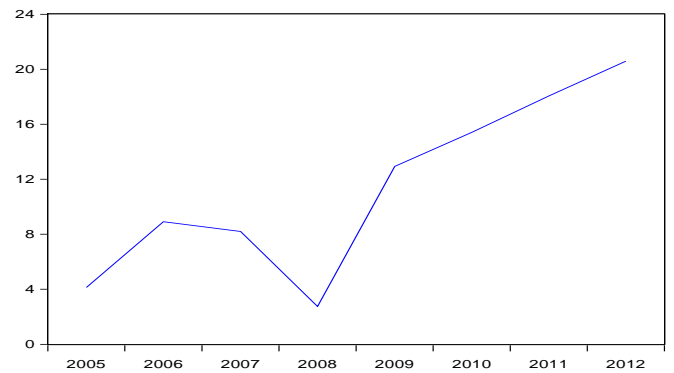

Figure 1 The evolution of the credit risk in Romania

Source: own computations using the data from Bankscope

Regarding the analyzed period, the Figure 2 highlights the decisions of the National Bank of Romania to reduce the monetary policy rate, decisions that were in line with the one adopted by the major central banks.

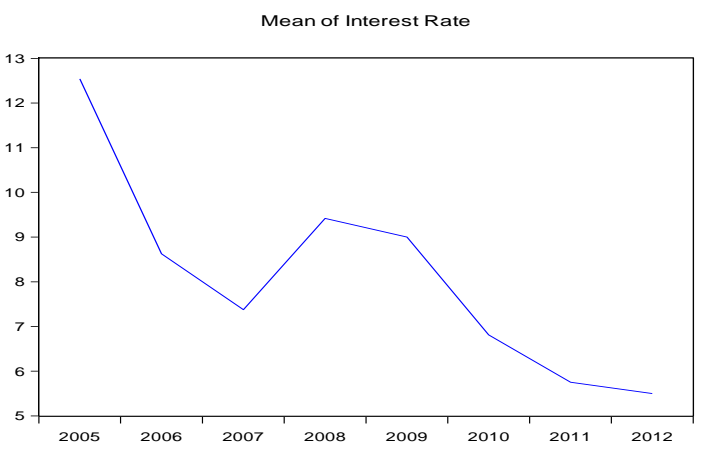

Figure 2 The evolution of the monetary policy rate in Romania

Source: own computations using the data from Bankscope database

\section{Results}

The aim of our empirical estimation is to investigate the relation between the monetary policy rate and the bank credit risk in Romania. We use the Panel Least Squares estimation method and the results are reported in Table 1.

Table 1 The impact of monetary policy on credit risk

\begin{tabular}{ll} 
Interest rate & $-2.793^{*}$ \\
& $(0.78)$ \\
Capitalization & -0.366 \\
& $(0.75)$ \\
Profitability & -0.194 \\
& $(1.99)$ \\
Size & -3.850 \\
& $(5.16)$ \\
\hline R-Squared & 0.726 \\
No. of observation & 68 \\
Estimation method & Cross-section fixed effects \\
Cluster & banks \\
& Source: own computations
\end{tabular}


Our results point to a negative relation between the interest rate and the credit risk, highly statistically significant. This means that the low levels of key policy rate that were adopted after the 2008 financial crisis have led to a higher level of bank risktaking. Our results are in line with the one obtained in the literature regarding the existence of a risk-taking channel of monetary policy. Also, our results highlight a negative relation between the credit risk and the three control variables that we used in our analysis. In Romania, in the period 2005 to 2012, highly capitalized banks exhibit low credit risk, while large banks with high profitability ratios have lower levels of bank risk-taking. However, we cannot account very much for the results obtained in case of the control variables, because they are not statistically significant.

\section{Table 2 The impact of the financial crisis on the relation between monetary} policy and credit risk

\begin{tabular}{ll} 
Interest rate & $-4.527^{*}$ \\
& $(1.48)$ \\
Interest rate * CRISIS & $1.459^{* *}$ \\
& $(0.64)$ \\
Capitalization & -0.825 \\
& $(0.904)$ \\
Profitability & 0.749 \\
& $(1.99)$ \\
Size & -16.36 \\
& $(8.70)$ \\
\hline R-Squared & 0.795 \\
No. of observation & 68 \\
Estimation method & Cross-section fixed effects \\
Cluster & banks \\
& Source: own computations
\end{tabular}

The second focus of our interest is to see whether the 2008 financial crisis had an impact on the relation between the interest rate and the credit risk. In order to do this, we estimate our baseline regression by including the dummy variable CRISIS that captures exactly the effects of the financial crisis. The results are shown in Table 2.

The negative sign of the coefficient for interest rate variable shows that low levels of interest rate lead to higher credit risk. However, if we look at the positive coefficient of the interaction term between interest rate and the variables that captures the effects of the crisis, we can observe that the negative impact of low levels of interest rate on credit risk is reduced in the years after the outbreak of the crisis. This means that the credit risk of commercial banks from the Romania banking system is lower after the crisis than before. The role of the dummy variable is to capture this difference. Also we can notice that the result for the interaction term is statistically significant, which means that the financial crisis that started in 2008 influenced the relation between interest rate and credit risk in Romania.

\section{Conclusion}

The financial crisis that started in late 2007 was such a major event that it still produces effects on the whole macro-economy. The aim of our paper is to analyze the effects of the interest rates adopted by National Bank of Romania in the period 20052012 on the credit risk of commercial banks and to investigate whether the crisis influences this relation. The results point to a negative relation between interest rate and bank risk, statistically significant and, also, to a significant impact of financial crisis on this relation. 
Our results are in line with the literature regarding the effects of interest rates on bank risks and especially with the most recent literature that investigates the impact of the very low levels of interest rates.

Although our analysis brings as novelty the fact that it is focused on the Romania's monetary policy, it has some limitations. The major limit regards the relative small size of our panel dataset that may bias the results.

\section{Acknowledgement}

This work was supported by a grant of the Romanian National Authority for Scientific Research and Innovation, CNCS - UEFISCDI, project number PN-II-RU-TE-2014-40443.

\section{References}

Andries, A., Cocris, V., Plescau, I. (2015), Low interest rates and bank risk-taking: has the crisis changed anything? Evidence from Eurozone, Review of Economic and Business Studies, Vol. VIII, Issue no. 1, 125-148.

Baumeister, C., Benati, L. (2013), Unconventional Monetary Policy and the Great Recession: Estimating the Macroeconomic Effects of a Spread Compression at the Zero Lower Bound, International Journal of Central Banking, 9, 165-212.

Bernanke, B., Reinhart, V. (2004), Conducting monetary policy at very low shortterm interest rates, The American Economic Review, 94(2), 85-90.

Borio, C., Disyatat, P. (2009), Unconventional monetary policies: and appraisal, BIS Working Papers, No. 292.

Friedman, B. (2013), The simple analytics of monetary policy: a post-crisis approach, Journal of Economic Education, 44(1), 311-328.

Peersman, G. (2011), Macroeconomic effects of unconventional monetary policy in the Euro Area, CESifo Working Papers, No. 3589. 